\title{
Inhibition of Early Vaccinia Virus Ribonucleic Acid Synthesis in Interferon-Treated Chicken Embryo Fibroblasts
}

\author{
H. S. BIALY AND C. COLBY \\ Microbiology Section, University of Connecticut, Storrs, Connecticut 06268
}

Received for publication 2 September 1971

\begin{abstract}
Pretreatment of chicken embryo cells with homologous but not heterologous interferon inhibits the synthesis of vaccinia virus early messenger ribonucleic acid (mRNA). This inhibition is seen in the presence of cycloheximide, i.e., in the absence of protein synthesis, suggesting that the virion-bound transcriptase may be the target of the antiviral activity associated with interferon treatment. The inhibition of viral mRNA synthesis is dependent on the amount of chicken interferon used. The nonviral interferon inducer, polyriboinosine - polyribocytidine, similarly inhibits viral early mRNA synthesis in a dose-specific manner. The helical polynucleotide polydeoxyinosine-polyribocytidine, which is not an effective interferon inducer in chicken embryo cells, has no effect on viral ribonucleic acid synthesis.
\end{abstract}

Recent experiments by Marcus et al. (P. I. Marcus et al., Science, in press) demonstrate that the virion-bound transcriptase of vesicular stomatitis virus (VSV) is inhibited in vivo by pretreatment of the cells with interferon. Since vaccinia virus also contains a virion-bound transcriptase (13) and since the replication of vaccinia virus in the cytoplasm of infected cells is sensitive to the antiviral action of interferon (10), we have tested the sensitivity of the vaccinia transcriptase in vivo to pretreatment of the cells with two interferon preparations and with helical polynucleotides.

\section{MATERIALS AND METHODS}

Chicken interferon was prepared from the medium of Sindbis virus-infected aged chicken embryo fibroblasts (1) by the method of Lampson et al. (14). Mouse interferon was prepared by the same method from the medium of mouse $\mathrm{L}$ cells infected with ultraviolet (UV)-irradiated Newcastle disease virus. The plaque reduction assay $\left(1 \mathrm{PR}_{50}\right.$ unit $=$ the concentration of interferon that reduces the plaque titer of a challenge virus by $50 \%$ ) was used with both interferons; vaccinia was the challenge virus in the case of chicken interferon, and VSV was the challenge virus for mouse interferon.

Vaccinia virus (strain WR) was grown in suspension cultures of HeLa cells and purified by the method of Joklik (8). The virus was plaque-titered on chicken embryo cells. Vaccinia deoxyribonucleic acid (DNA) was prepared from purified virions by the method of Kates and Beeson (11). The methods for preparing pulse-labeled vaccinia virus ribonucleic acid (RNA) from the cytoplasm of infected cells and for hybridizing this RNA to vaccinia DNA have been described $(3,5)$.

Polyriboinosine[poly(rI)]·polyribocytidine[poly $(\mathrm{rC})]$ was purchased from P-L Biochemicals. Polydeoxyinosine[poly(dI)] polyribocytidine[poly(rC)] was obtained from M. J. Chamberlin. Procedures for inducing the interferon response in chicken embryo cells with helical polyribonucleotides and diethylaminoethyl-dextran have been described (2).

\section{RESULTS}

Secondary cultures of chicken embryo cells were exposed to interferon for $20 \mathrm{hr}$. Interferontreated and untreated cultures were then infected with vaccinia virus, (35 plaque-forming units/ cell), in the presence of $50 \mu \mathrm{g}$ of cycloheximide per $\mathrm{ml}$. The use of this antimetabolite to eliminate protein synthesis insures that the synthesis of vaccinia messenger RNA (mRNA) is catalyzed only by the virion-bound polymerase (12). We allowed $1 \mathrm{hr}$ for virus penetration and cell-mediated removal of the viral envelope, and followed viral RNA synthesis by pulsing the cells for 12 min with ${ }^{3} \mathrm{H}$-uridine. Vaccinia RNA and cellular transfer RNA are the only RNA species in the cytoplasm that are labeled under these conditions (9).

The RNA in the cytoplasm was extracted and purified by sodium dodecyl sulfate-Pronasephenol treatment and precipitated with ethanol. Table 1 presents the results from such an experiment. It can be seen that pretreatment of the cells with 400 units of chicken interferon apparently 
TABLE 1. Effect of interferon pretreatment on vaccinia virus early messenger ribonucleic acid $^{a}$

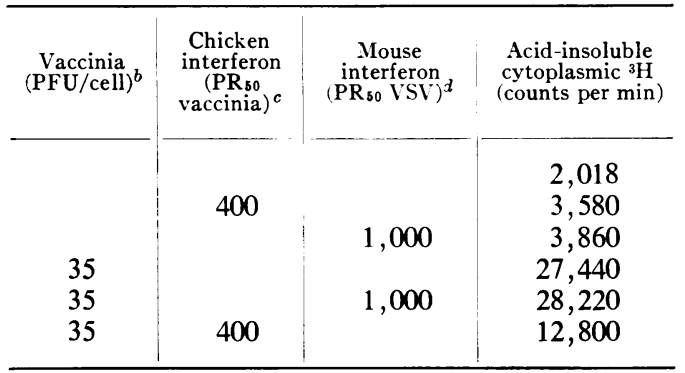

a Interferons in the amounts indicated in the table were added to $100-\mathrm{mm}$ dishes of confluent chicken embryo cultures in $8 \mathrm{ml}$ of $\mathrm{NCl}$ medium (Schwartz BioResearch)) containing $2 \%$ heated calf serum. After incubation for $24 \mathrm{hr}$ at $39 \mathrm{C}$ to allow the establishment of the interferon block, the medium was removed and $8 \mathrm{ml}$ of $\mathrm{NCl} \pm 2 \%$ heated calf serum containing $50 \mu \mathrm{g}$ of cycloheximide per $\mathrm{ml}$ was added to the cultures. The dishes were incubated for $10 \mathrm{~min}$ at $37 \mathrm{C}$, after which the medium was removed and $0.8 \mathrm{ml}$ of $\mathrm{NCl}$ plus $2 \%$ heated calf serum plus cycloheximide $(50 \mu \mathrm{g} / \mathrm{ml})$ plus vaccinia virus strain WR was added. The virus was allowed to adsorb to the cells for $30 \mathrm{~min}$ at $37 \mathrm{C}$. The medium was replaced and incubation continued for an additional $60 \mathrm{~min}$, after which the medium was removed from all plates and $2 \mathrm{ml}$ of a labeling solution, containing $\mathrm{NCl}$ plus $2 \%$ dialyzed calf serum, $50 \mu \mathrm{g}$ of cycloheximide per $\mathrm{ml}$, and $100 \mu \mathrm{Ci}$ of ${ }^{3} \mathrm{H}$-uridine per $\mathrm{ml}$ was added. The dishes were incubated at $37 \mathrm{C}$ for $12 \mathrm{~min}$ with agitation every $5 \mathrm{~min}$ and then transferred to an ice-slurry. The labeling solution was removed and the plates were washed with $5 \mathrm{ml}$ of ice cold phosphate-buffered saline (PBS). An additional $5 \mathrm{ml}$ of cold PBS was then added and the cells were removed from the plate with a rubber policeman. The plates were washed with cold PBS and the combined suspension of cells was centrifuged for $3 \mathrm{~min}$ at $2,000 \mathrm{rev} / \mathrm{min}$. The cellular pellet was resuspended in $2 \mathrm{ml}$ of cold hypotonic buffer of the following composition: $0.025 \mathrm{M} \mathrm{KCl}, 0.002$ $\mathrm{M} \mathrm{MgCl}_{2}, 0.005 \mathrm{M} \mathrm{CaCl}_{2}, 0.01 \mathrm{M}$ tris(hydroxymethyl)aminomethane (Tris)-hydrochloride ( $p \mathrm{H}$ 7.4), $0.1 \%$ Triton $X-100$, and allowed to swell on ice for 5 to $10 \mathrm{~min}$ before being gently dounced 12 to 15 times. Nuclei and cellular debris were removed by centrifugation and to the supernatants were added sodium dodecyl sulfate, $(0.5 \%$ final concentration) and Pronase $(0.5 \mathrm{mg} / \mathrm{ml}$ final concentration). After incubation at $37 \mathrm{C}$ for $30 \mathrm{~min}$, the solutions were extracted three times with phenol, and the ribonucleic acid (RNA) was precipitated by the addition of 2 volumes of cold absolute ethanol. The RNA was collected by centrifugation and redissolved in $0.01 \mathrm{M}$ Trishydrochloride $(p \mathrm{H} \mathrm{7.4)}, 0.1 \mathrm{M} \mathrm{NaCl}$, and $0.001 \mathrm{M}$ ethylenediaminetetraacetic acid.

$b$ Plaque-forming units per cell.
TABLE 2. Dose-response inhibition of vaccinia virus early messenger ribonucleic acid synthesis by interferon ${ }^{a}$

\begin{tabular}{|c|c|c|}
\hline $\begin{array}{c}\text { Vaccinia } \\
\text { (PFU/cell) }\end{array}$ & $\begin{array}{c}\text { Chicken interferon } \\
\left.\text { (PR } \text { PRo vaccinia/ }^{\prime} 0^{7} \text { cells }\right)\end{array}$ & $\begin{array}{c}\text { Acid-insoluble }{ }^{3} \mathrm{H} \\
\text { counts per min } \\
\text { (post-agarose) }\end{array}$ \\
\hline & & 8,200 \\
\hline 35 & & 30,700 \\
\hline 35 & 80 & 24,300 \\
\hline 35 & 160 & 13,500 \\
\hline 35 & 320 & 5,300 \\
\hline
\end{tabular}

${ }^{a}$ The cultures were treated and the ribonucleic acid (RNA) was prepared as described in footnote $a$, Table 1, except that the final RNA solution was further purified by gel filtration on a $6^{C_{C}}$ agarose column (3).

${ }^{b}$ Plaque-forming units per cell.

c See Table 1, footnote $c$.

inhibits the viral enzyme by $50 \%$, whereas pretreatment of the cells with 1,000 units of heterologous mouse interferon has no effect on early vaccinia virus RNA synthesis.

We then treated chicken cells with various concentrations of interferon, infected then with vaccinia virus in the presence of cycloheximide, and extracted the pulse-labeled cytoplasmic RNA as before. This RNA was then subjected to gel filtration on a $6 \%$ agarose column. The low-molecularweight RNA is retarded on such a column, whereas vaccinia mRNA appears in the void volume (3). The results presented in Table 2 show the dose-dependent inhibition of vaccinia virus early mRNA synthesis by pretreatment with interferon. We routinely find 80 to $85 \%$, inhibition of early mRNA synthesis by pretreatment with 320 units of chicken interferon when the RNA is purified in this manner.

A trivial explanation of these results is that interferon pretreatment and vaccinia virus infection markedly alters the intracellular pools of uridine, rendering the incorporation of ${ }^{3} \mathrm{H}$-uridine into acid-insoluble material an inaccurate measure of RNA synthesis. We therefore measured the soluble intracellular pools of uridine under the experimental conditions described above and found fluctuations of less than $10 \%$. These data are presented in Table 3. We therefore conclude that our measurements reflect the rate of RNA synthesis in these cells.

\footnotetext{
${ }^{c}$ One plaque-reduction unit $\left(1 \mathrm{PR}_{50}\right)$ equals the concentration of interferon that reduces the plaque titer of vaccinia virus by $50 \%$.

${ }^{d}$ One $\mathrm{PR}_{50}$ VSV unit equals the concentration of interferon that reduces the plaque titer of vesicular stomatitis virus by $50 \%$.
} 
TABLE 3. Effect of interferon pretreatment and vaccinia virus infection on the intracellular pools of uridine ${ }^{a}$

\begin{tabular}{c|c|c}
\hline $\begin{array}{c}\text { Vaccinia } \\
\left(\mathrm{PFU} / \mathrm{cell}^{b}\right.\end{array}$ & $\begin{array}{c}\text { Chicken interferon } \\
\left(\mathrm{PR}_{60} \text { vaccinia }\right)^{c}\end{array}$ & $\begin{array}{c}\text { Intracellular uridine } \\
\left({ }^{3} \mathrm{H} \text { counts per min }\right. \\
\left.\times 10^{5}\right)\end{array}$ \\
\hline & & 1.66 \\
35 & 400 & 1.55 \\
35 & 400 & 1.66 \\
& & 1.52 \\
\hline
\end{tabular}

${ }^{a}$ The conditions of interferon treatment, infection with vaccinia virus, and a period of labeling with ${ }^{3} \mathrm{H}$-uridine were as described for Table 1. The intracellular soluble pools of $\mathbf{H}^{3}-$ uridine were determined as previously described (4). The values in the table represent an average of duplicate experiments. The efficiency of uptake of ${ }^{3} \mathrm{H}$-uridine by the cells during the 12 -min pulse was $6 \%$.

${ }^{b}$ Plaque-forming units per cell.

${ }^{c}$ See Table 1, footnote $c$.

The RNA from these experiments was tested for its sequence homology with vaccinia virus DNA by DNA-RNA hybridization. The results of these experiments (Table 4) show that approximately $50 \%$ of the pulse-labeled ${ }^{3} \mathrm{H}-\mathrm{RNA}$ extracted from cells which had been infected with vaccinia was able to hybridize with vaccinia DNA, whereas none of the RNA extracted from the uninfected cells was capable of forming such a hybrid. The fact that a constant fraction of the input RNA was hybridizable indicates that only a small amount of chicken RNA is present in these samples.

A further indication that the inhibition of early mRNA synthesis is mediated by the interferon response comes from experiments using the nonviral interferon inducer, poly $(\mathrm{rI}) \cdot$ poly $(\mathrm{rC})$. The results presented in Table 5 show that pretreatment with increasing amounts of $(\mathrm{rI})_{n} \cdot(\mathrm{rC})_{n}$ inhibits the synthesis of early viral mRNA. An additional control was included in this experiment, namely a helical polynucleotide homopolymer pair, $(\mathrm{dI})_{n} \cdot(\mathrm{rC})_{n}$, which is not an effective interferon inducer in these cells (2) and which did not reduce the level of viral mRNA.

\section{DISCUSSION}

The results of our experiments indicate that pretreatment of chicken embryo cells with interferon markedly reduces the synthesis of vaccinia virus early mRNA. This is in contrast with the results reported by Joklik and Merigan (10), who found no inhibition of pulse-labeled cytoplasmic RNA in interferon-treated mouse $\mathbf{L}$ cells infected with vaccinia virus. These conflicting results are
TABLE 4. Hybridization of $H^{3}$-cytoplasmic ribonucleic acid $(R N A)$ with vaccinia deoxyribonucleic acid ${ }^{a}$

\begin{tabular}{l|r|r}
\hline \multicolumn{1}{c|}{ Source of input RNA } & $\begin{array}{r}{ }^{3} \mathrm{H} \text { counts } \\
\text { per min } \\
\text { input RNA }\end{array}$ & $\begin{array}{r}{ }^{3} \mathrm{H} \text { Counts } \\
\text { per min } \\
\text { hybridized }\end{array}$ \\
\cline { 2 - 3 } Vaccinia-infected chicken & 3,000 & 1,451 \\
cells & 6,000 & 3,077 \\
& 12,000 & 5,647 \\
Vaccinia-infected chicken & 2,400 & 1,387 \\
cells pretreated with 80 & 4,800 & 2,365 \\
units of interferon & 9,600 & 5,032 \\
& & \\
Vaccinia-infected chicken & 1,350 & 502 \\
cells pretreated with 160 & 2,700 & 955 \\
units of interferon & 5,400 & 1,767 \\
Vaccinia-infected chicken & 530 & 297 \\
cells pretreated with 320 & 1,060 & 557 \\
units of interferon & 2,120 & 1,171 \\
Uninfected, noninterferon- & 1,640 & 4 \\
treated chicken cells & 3,280 & 12 \\
\hline
\end{tabular}

${ }^{a}$ Vaccinia DNA $(5 \mu \mathrm{g})$ was immobilized on each filter, and hybridization was performed as described in Materials and Methods. The time allowed for the hybridization reaction was $20 \mathrm{hr}$. The numbers in column three represent ${ }^{3} \mathrm{H}$ counts per minute bound after subtraction of the ${ }^{3} \mathrm{H}$ counts per minute bound to a blank filter in the same vial. The latter was routinely 25 counts per $\min$.

most likely related to differences in the two cell systems rather than to the mechanism of action of interferon. Joklik and Merigan (10) pointed out that vaccinia virus displays severe cytotoxic effects in mouse $\mathbf{L}$ cells. Horak et al. (7) have recently shown that $\mathbf{L}$ cells pretreated with interferon and infected with vaccinia virus develop a drastic cytopathic effect, which differs morphologically from the usual cytopathic effects observed in poxvirus-infected cells. They followed the destruction of the cells by measuring the release of ${ }^{51} \mathrm{Cr}$ from the cells into the medium and showed that the effects depended one one or more late viral functions. In an earlier report, Horak et al. (6) reported an inhibition of poxvirus RNA synthesis in mouse $\mathbf{L}$ cells when the cytoplasmic RNA was extracted by a gentle detergent lysis, rather than the more radical mechanical lysis used by Joklik and Merigan (10).

The hypothesis of Marcus et al. (P. I. Marcus et al., Science, in press) that transcription of early viral RNA may be a site of interferon action arose from experiments in which the virion-bound transcriptase of VSV appeared to be less active in 
TABLE 5. Inhibition of vaccinia virus early messenger ribonucleic acid synthesis by polyriboinosine $[$ poly $(r I)] \cdot$ polyribocytidine $[\operatorname{poly}(r C)]^{a}$

\begin{tabular}{c|c|c|c}
\hline $\begin{array}{c}\text { Vaccinia } \\
\left(\mathrm{PFU} / \mathrm{cell}^{b}\right.\end{array}$ & $\begin{array}{c}(\mathrm{rI})_{\mathrm{n}} \cdot(\mathrm{rC})_{\mathrm{n}} \\
(\mu \mathrm{g} / \mathrm{ml})\end{array}$ & $\begin{array}{c}(\mathrm{dI})_{\mathrm{n}} \cdot(\mathrm{rC})_{\mathrm{n}}{ }^{c} \\
(\mu \mathrm{g} / \mathrm{ml})\end{array}$ & $\begin{array}{c}\text { Acid-insoluble } \\
\text { cytoplasmic } \\
\mathrm{H}^{3} \text { counts per } \\
\text { min }\end{array}$ \\
\hline & & & 4,550 \\
& 10.0 & & 4,106 \\
35 & 0.1 & & 6,798 \\
35 & 1.0 & & 5,721 \\
35 & 10.0 & & 3,243 \\
35 & & 10.0 & 2,990 \\
35 & & & 6,440 \\
\hline
\end{tabular}

${ }^{a}$ This experiment was performed as described in Table 1 , footnote $a$, except that $35-\mathrm{mm}$ dishes of chicken cells were used instead of $100-\mathrm{mm}$ ones. Pretreatment of the cells with the synthetic polynucleotides is described in Materials and Methods.

${ }^{b}$ Plaque-forming units per cell.

$c$ Deoxyinosine (dI) - ribocytidine (rC).

interferon-treated chicken cells. This observation has been confirmed in another cell system, namely VSV-infected human cells (A. Huang and E. Manders, personal communication), and our experiments extend the observation to yet another virus system, namely, vaccinia-infected chicken cells. Furthermore, in the case of simian virus 40 , Oxman and Levin (15) have demonstrated an inhibition of early virus-specific RNA synthesis by pretreatment by interferon. Thus, three viruses that replicate in quite dissimilar fashions, a cytoplasmic DNA virus, a cytoplasmic RNA virus and a nuclear DNA virus, show a remarkable similarity in their sensitivity to interferon.

Although these results argue for a transcriptional block as a site of action of the interferon system, they certainly do not eliminate the possibility that viral translation is also a target of interferon-induced inhibition. Finally, until one is able to demonstrate an interferon-mediated effect in vitro on either viral transcriptase systems or viral protein-synthesizing systems that initiate and terminate with fidelity, all in vivo data must be taken as indicative and not conclusive.

\section{ACKNOWLEDGMENTS}

H. S. B. is supported by a Damon Runyon Cancer Research Fellowship. C. C. is supported by a Public Health Service career development award. This research was supported by Public Health Service research grant AI 10096 from the National Institute of Allergy and Infectious Diseases and by a research grant from the Connecticut Research Foundation. We are grateful for the privilege of seeing a copy of the manuscript of Marcus et al. (15) prior to its publication.

\section{LITERATURE CITED}

1. Carver, D. H., and P. I. Marcus. 1967. Enhanced interferon production from chick embryo cells aged in vitro. Virology 32:247-257.

2. Colby, C., and M. J. Chamberlin. 1969. The specificity of interferon induction in chick embryo cells by helical rna. Proc. Nat. Acad. Sci. U.S.A. 63:160-167.

3. Colby, C., and P. H. Duesberg. 1969. Double-stranded RNA in vaccinia virus infected cells. Nature (London) 222:940944.

4. Colby, C., and H. Rubin. 1969. Growth and nucleic acid synthesis in normal cells and cells infected with rous sarcoma virus. J. Nat. Cancer Inst. 43:437-444.

5. Duesberg, P. H., and C. Colby. 1969. On the biosynthesis and structure of double-stranded RNA in vaccinia virus infected cells. Proc. Nat. Acad. Sci. U.S.A. 64:396-403.

6. Horak, I., J. Hilfenhaus, W. Siegert, C. Jungwirth, G. Bodo, and P. Palese. 1970. Interferon action: effect on the formation of poxvirus specific polysomes and viral RNA. Z. Naturforsch. Teil. B 25:1164-1170.

7. Horak, I., C. Jungwirth, and G. Bodo. 1971. Poxvirus specific cytopathic effect in interferon-treated L-cells. Virology 45: 456-462.

8. Joklik, W. J. 1964. The intracellular uncoating of poxvirus DNA. I. The fate of radioactively-labeled rabbitpox virus. J. Mol. Biol. 8:263-276.

9. Joklik, W. K. 1968. In H. Fraenkel Conrat (ed.), The molecular basis of virology. New York Reinhold Book Corp., p 576.

10. Joklik, W. K., and T. C. Merigan. 1966. Concerning the mechanism of action of interferon. Proc. Nat. Acad. Sci. U.S.A. 56:558-565.

11. Kates, J., and J. Beeson. 1970. Ribonucleic acid synthesis in vaccinia virus. $I$. The mechanism of synthesis and release of RNA in vaccinia cores. J. Mol. Biol. 50:1-8.

12. Kates, J., and B. R. McAuslan. 1966. Messenger RNA synthesis by a coated viral genome. Proc. Nat. Acad. Sci. U.S.A. 57:314-320.

13. Kates, J., and B. R. McAuslan. 1967. Poxvirus DNA-dependent RNA polymerase. Proc. Nat. Acad. Sci. U.S.A. 58:134-141.

14. Lampson, G. P., A. A. Tytell, M. M. Nemes, and M. R. Hilleman. 1963. Purification and characterization of chick embryo interferon. Proc. Soc. Exp. Biol. Med. 112:468-478.

15. Oxman, M. N., and M. J. Levin. 1971. Interferon and transcription of early virus-specific RNA in cells infected with simian virus 40. Proc. Nat. Acad. Sci. U.S.A. 68:299-302. 